\title{
Internet-Based Learning in Increasing Student Learning Activities in Learning the Basic Concepts of Dance
}

\author{
Dwi Anggraini* and Hasnawati
}

\author{
Primary School Teacher Education Study Program, University of Bengkulu, Indonesia \\ *Corresponding author. Email: dwianggraini@unib.ac.id
}

\begin{abstract}
This study aims to describe the increase in student activity by utilizing the internet in learning the Basic Concepts of Dance Material of Tari Nusantara for VB semester students of PGSD Study Program, University of Bengkulu. The research method used is action research by Kemmis-Mc Taggart Model which was carried out in 2 cycles. The data collection technique is the participant observation of student activity which is analyzed using percentage analysis. The data analyzed were student activity data during the learning of the Basic Concepts of Dance using the internet. The data validity technique used was observation persistence. The results showed that in cycle 1 , the activities of students who were in the enough category were $35.71 \%$, and $64.29 \%$ were in the good category. It is increased in cycle 2 , namely $42.86 \%$ in the good category and 57.14 in the very good category. This shows that the results of the study have answered the indicators of success, namely that all aspects at least are in the enough category and increase in the next cycle.
\end{abstract}

Keywords: Internet, Learning activities, Students, Nusantara dance, Basic concepts of dance.

\section{INTRODUCTION}

This article is the result of a study written into two articles. The previous article was in the publication process stage about increasing student literacy by utilizing the internet in learning the basic concepts of dance, where the results showed that student literacy increased in each cycle. In this article, what will be discussed is about increasing student activity by utilizing the internet in learning the basic concepts of dance.

Research on learning using the internet to increase learning activities has been carried out. Previously, a survey research was conducted on the use of the internet as a substitute for libraries and the obstacles experienced by students at the University of Pattimura Ambon [1], integration of active learning and internetbased learning to explain the supporting and inhibiting factors for PGMI students and STAIN Ponorogo lecturers [2], controlling electronic devices in the form of LED lights using an Arduino uno microcontroller by utilizing the internet [3], Arduino IoT implementation is used as an Embedded System device in controlling electronic devices [4].
There are so many benefits that we get by using the internet. Everything is easily accessible and available to everyone. In addition, it can also encourage students to think critically and solve problems independently without being limited by space and time [5]. Using the internet in learning can provide motivation to students, however, the role of the teacher remains in a very important position [6]. Internet as a learning resource can provide more information to students and improve their learning achievement [7]. Internet makes students active in accessing learning resources without having to meet face to face with teachers in class [8].

The use of the internet, such as Google and Youtube, which is legalized during the learning process in the classroom rarely occurs in the PGSD Study Program, University of Bengkulu. Based on observations made in learning the Basic Concepts of Dance, students use Google only during presentations to find answers to questions raised by their friends during discussions. This was done without being noticed by the lecturer who was teaching at that time. This kind of behavior makes learning less meaningful and unpleasant. Student activeness in the classroom becomes apparent because they actually do improper tricks to appear active and 
involved in discussion sessions without knowing what meaning they get from the information they get on the internet. The reason is that there is no legality of using the internet in learning. So that students improvise themselves without being guided by a lecturer. Students prefer to complete their assignments at home to complete them in class. Because according to him, it will be easier to access the internet at home.

In this regard, this research was conducted to increase student activity on the basic concepts of dance, archipelago dance by utilizing Google and Youtube. This research is expected not only to affect the literacy of Indonesian dance, considering that in this global era literacy is very important to be mastered [9][10], but also in learning activities.

Nusantara dance material is a material that studies dances from Sabang to Merauke and is a material that must be mastered by prospective elementary school teachers. With Google and Youtube, this can be easier. Because as has been said before that the internet provides a variety of information that can be accessed easily by everyone without any time and space restrictions [7]. Learning activities using the internet are popular learning in the era of the industrial revolution 4.0 and the era of globalization. The changes brought about by globalization are inevitable. Globalization brings changes to the lifestyle and social systems in the world [11].

\section{RESEARCH METHOD}

The research method used was an action research model by Kemmis and Mc Taggart which was conducted in two cycles, because action research was an attempt to improve the learning process in the classroom by the teacher [12]. In action research, treatment is given intentionally to solve problems or improve class quality [13]. The data collection technique used was participant observation with data analysis, namely the percentage. The data analyzed were students' activities in learning the Basic Concepts of Dance in Nusantara Dance with the use of the internet, namely Google and YouTube. The data validity technique used was increased persistence. The indicator of the success of this study is that student activity is in the sufficient category and increases in the next cycle.

The research subjects were 38 semester VB students of PGSD study program, University of Bengkulu, consisting of 5 boys and 33 girls. The data collection technique is observation using the student activity observation sheet instrument with 14 aspects that must be observed. These aspects are observed by providing a checklist in the category table with a range of 1 to 4 . The following aspects are observed.
Table 1. Observed Aspects of Student Activities

\begin{tabular}{|c|c|c|c|c|c|}
\hline \multirow{2}{*}{ No } & \multirow{2}{*}{ Aspects Observed } & \multicolumn{4}{|c|}{ Score } \\
\hline & & 1 & 2 & 3 & 4 \\
\hline 1 & $\begin{array}{l}\text { Students condition } \\
\text { themselves to be ready to } \\
\text { learn }\end{array}$ & & & & \\
\hline 2 & $\begin{array}{l}\text { Students listen to the } \\
\text { learning objectives } \\
\text { conveyed by the lecturer. }\end{array}$ & & & & \\
\hline 3 & $\begin{array}{l}\text { Students listen as the } \\
\text { lecturer explains Nusantara } \\
\text { dance material using the } \\
\text { internet }\end{array}$ & & & & \\
\hline 4 & $\begin{array}{l}\text { Students form } \\
\text { heterogeneous groups }\end{array}$ & & & & \\
\hline 5 & $\begin{array}{l}\text { Students listen to group } \\
\text { discussion assignments } \\
\text { given by the lecturer }\end{array}$ & & & & \\
\hline 6 & $\begin{array}{l}\text { Students } \\
\begin{array}{l}\text { Nusantara dance observe } \\
\text { internet }\end{array}\end{array}$ & & & & \\
\hline 7 & $\begin{array}{l}\text { Students } \\
\text { Nusantara dance which } \\
\text { includes themes, } \\
\text { movement characteristics, } \\
\text { music, costumes, floor } \\
\text { patterns, and properties } \\
\text { used }\end{array}$ & & & & \\
\hline 8 & $\begin{array}{l}\text { Students discuss the theme, } \\
\text { movement characteristics, } \\
\text { music, costumes, floor } \\
\text { patterns, and props used } \\
\text { with the group and practice } \\
\text { the dance }\end{array}$ & & & & \\
\hline 9 & $\begin{array}{ll}\text { Students } & \text { practice } \\
\text { Nusantara dance }\end{array}$ & & & & \\
\hline 10 & $\begin{array}{l}\text { Students present the results } \\
\text { of the discussion and the } \\
\text { results of the exercises in } \\
\text { front of the class }\end{array}$ & & & & \\
\hline 11 & $\begin{array}{l}\text { Express their opinion } \\
\text { about the dance based on } \\
\text { the results of their } \\
\text { discussions } \\
\text { presentations }\end{array}$ & & & & \\
\hline 12 & $\begin{array}{l}\text { Students ask questions } \\
\text { about the material that has } \\
\text { been studied }\end{array}$ & & & & \\
\hline 13 & $\begin{array}{l}\text { Students conclude the } \\
\text { learning material that has } \\
\text { been studied }\end{array}$ & & & & \\
\hline 14 & $\begin{array}{l}\text { Students listen to the } \\
\text { lecturer to close the lesson }\end{array}$ & & & & \\
\hline & amount & & & & \\
\hline & Percentage & & & & \\
\hline
\end{tabular}

The results of the observations were then analyzed using the percentage technique using the following formula [14].

$$
P=\frac{F}{N} x 100 \%
$$


Each aspect of each category of the assessment score is added and a percentage to obtain data about student activities in the learning process of the Basic Concepts of Dance.

The action research procedure used consists of four stages, namely planning, implementing, observing and reflecting [14] which are carried out in 2 cycles and 2 meetings in each cycle. At the planning stage, the researcher identifies the problem and determines the action to be taken. The problem is found in learning activities on Nusantara dance material. Furthermore, designing learning using the internet by discussing with other research teams and designing learning activity instruments is important. At the implementation stage, the material is broadly presented using the internet; students are divided into 7 groups consisting of 5-6 people per group and look for agreed-upon Nusantara dances using the internet. Then the students make observations and identify the Nusantara dance including the theme, movement characteristics, costumes, floor patterns and properties used and practicing it. The results of group discussions and dance exercises are presented in front of the class.

The next stage is observation. At this stage, it is carried out during the learning process using predesigned instruments with colleagues. Observations were made to see student activities in learning the Basic Concepts of Dance in Nusantara dance material by utilizing the internet. The last stage is reflection. At this stage, the results of student activity observations are analyzed and the results are used as a guide for preparing plans in cycle II if the expected results have not been achieved. This research is said to be successful if it meets the indicators of success, namely student activeness at least in the sufficient category (score 3) and increases in the next cycle.

\section{RESULTS AND DISCUSSION}

\subsection{Results}

\subsubsection{Description of Cycle 1}

Lecturers and students agreed on several dances to look for information, namely North Sumatra, South Sumatra, West Sumatra, Papua, Nanggroe Aceh Darussalam, South Sulawesi and Central Kalimantan. After that, students discuss traditional dances or creations and seek information about these dances in groups. The implementation of learning the Basic Concepts of Dance in Cycle 1 is as follows.

Table 2. Learning steps The Basic Concepts of Dance Using The Internet In Cycle 1- Meeting 1

\begin{tabular}{|l|l|ll|}
\hline 1. & $\begin{array}{l}\text { First } \\
\text { activity }\end{array}$ & a. & $\begin{array}{l}\text { The lecturer asked all students } \\
\text { to pray } \\
\text { b. }\end{array}$ \\
& $\begin{array}{l}\text { Doing apperception } \\
\text { motivating students }\end{array}$ & and \\
\end{tabular}

\begin{tabular}{|c|c|c|c|}
\hline & & & $\begin{array}{l}\text { convey the objectives and } \\
\text { steps of the activities to be } \\
\text { carried out }\end{array}$ \\
\hline 2. & $\begin{array}{l}\text { Core } \\
\text { activitie } \\
\mathrm{S}\end{array}$ & a. & $\begin{array}{l}\text { Students listen to the } \\
\text { lecturers' explanation of } \\
\text { Nusantara dance and the } \\
\text { elements in dance (themes, } \\
\text { movement characteristics, } \\
\text { music, props, costumes and } \\
\text { others). } \\
\text { Students ask questions related } \\
\text { to Nusantara dance and its } \\
\text { supporting elements. } \\
\text { Students listen to lecturers' } \\
\text { explanations about things that } \\
\text { students have not understood } \\
\text { about the material that has } \\
\text { been explained. } \\
\text { Students are divided into } 7 \\
\text { groups consisting of 5-6 } \\
\text { people per group. } \\
\text { Students listen to the lecturer } \\
\text { instructions about the } \\
\text { assignments to be done in the } \\
\text { group. } \\
\text { Students and lecturers agree } \\
\text { on the areas that the dance } \\
\text { will use in the learning } \\
\text { process. } \\
\text { Students are assigned to } \\
\text { determine the Nusantara } \\
\text { dance based on an agreement } \\
\text { and look for information and } \\
\text { videos by accessing the } \\
\text { internet through the media of } \\
\text { a laptop or cellphone. } \\
\text { Students observe Nusantara } \\
\text { videos and information shared } \\
\text { on the websites they access. } \\
\text { iStudents identify elements of } \\
\text { Students practice Nusantara } \\
\text { discussion and practice of } \\
\text { of Nusantara dance at home. } \\
\text { been agreed upon, including } \\
\text { themes, } \\
\text { characteristics, } \\
\text { costumes, floor patterns, and } \\
\text { properties used. } \\
\text { Students discuss the elements } \\
\text { espective groups. }\end{array}$ \\
\hline 3. & $\begin{array}{l}\text { End } \\
\text { activitie } \\
\mathrm{s}\end{array}$ & & $\begin{array}{l}\text { Students and lecturers } \\
\text { conclude the lecture material. } \\
\text { Lecturers provide moral } \\
\text { messages to students. } \\
\text { The lecturer invites students }\end{array}$ \\
\hline
\end{tabular}


to pray at the end of the lecture.

Table 3. Learning steps The Basic Concepts of Dance Using The Internet In Cycle 1- Meeting 2

\begin{tabular}{|c|c|c|}
\hline 1. & $\begin{array}{l}\text { First } \\
\text { activity }\end{array}$ & $\begin{array}{l}\text { a. The lecturer asked all students } \\
\text { to pray } \\
\text { b. Doing apperception and } \\
\text { motivating students. } \\
\text { c. Delivering the objectives and } \\
\text { steps for the activities to be } \\
\text { carried out. }\end{array}$ \\
\hline 2. & $\begin{array}{l}\text { Core } \\
\text { activities }\end{array}$ & $\begin{array}{l}\text { a. Students listen to lecturers' } \\
\text { directions regarding the } \\
\text { activities to be carried out } \\
\text { b. Students continue to practice } \\
\text { Nusantara dance. } \\
\text { c. Students present the results of } \\
\text { their discussions and } \\
\text { exercises in front of the class } \\
\text { d. Lecturers provide } \\
\text { opportunities for other } \\
\text { students to respond to the } \\
\text { results of the presentation of } \\
\text { the speaker group. } \\
\text { e. Students reflect on learning } \\
\text { outcomes. }\end{array}$ \\
\hline 3. & $\begin{array}{l}\text { End } \\
\text { activities }\end{array}$ & $\begin{array}{l}\text { a. Students and lecturers } \\
\text { conclude the lecture material. } \\
\text { b. Lecturers give moral } \\
\text { messages to students. } \\
\text { c. The lecturer invites students } \\
\text { to pray at the end of the } \\
\text { lecture. }\end{array}$ \\
\hline
\end{tabular}

Based on the learning process that has been carried out, the findings in cycle 1 can be explained as follows. The results of observations of student activities in learning the Basic Concepts of Dance in Nusantara dance material by using the internet to get information about dance can be seen in the following table.

Table 4. Data on the observation of student activities in cycle 1

\begin{tabular}{|l|c|c|}
\hline \multicolumn{1}{|c|}{ Criteria } & Total Score & Percentage (\%) \\
\hline Less & - & - \\
\hline Enough & 5 & 35.71 \\
\hline Good & 9 & 64.29 \\
\hline Very Good & - & - \\
\hline
\end{tabular}

Based on table 1, it can be seen that student activity is in the enough category $35.71 \%$ and good $64.29 \%$. However, it is not yet in the very good category. Aspects that are in the sufficient category and need improvement in cycle 2 are 1) Students listen to the learning objectives conveyed by the lecturer. 2) Students listen to group discussion assignments given by the lecturer, 3) Students discuss themes, movement characteristics, music, costumes, floor patterns, and properties used with the group and practice the dance, 4) Express opinions about the dance based on the results of discussions and presentations them, and 5) Students conclude the learning material that has been studied

\subsubsection{Description of Cycle 2}

The learning process in cycle 2 is an improvement in learning cycle 1 which is still in the sufficient category and if possible improve aspects that were originally in the good category to be very good. The following is the implementation of learning in cycle 2 .

Table 5. Learning steps The Basic Concepts of Dance Using The Internet In Cycle 2 - Meeting 1

\begin{tabular}{|c|c|c|}
\hline 1. & $\begin{array}{l}\text { First } \\
\text { Activity }\end{array}$ & $\begin{array}{l}\text { a. The lecturer asked all students to } \\
\text { pray } \\
\text { b. Doing apperception and motivating } \\
\text { students } \\
\text { c. convey the objectives and steps of } \\
\text { the activities to be carried out }\end{array}$ \\
\hline 2. & $\begin{array}{l}\text { Core } \\
\text { activitie } \\
\mathrm{S}\end{array}$ & $\begin{array}{l}\text { a. Students listen to lecturers' } \\
\text { explanations about Nusantara dance } \\
\text { literacy and elements in dance } \\
\text { (themes, movement characteristics, } \\
\text { music, props, costumes, etc.). } \\
\text { b. Students ask questions related to the } \\
\text { Nusantara dance and its supporting } \\
\text { elements. } \\
\text { c. Students listen to lecturers' } \\
\text { explanations about things that } \\
\text { students have not understood about } \\
\text { the material that has been explained. } \\
\text { d. Students are divided into } 7 \text { groups } \\
\text { consisting of 5-6 people per group. } \\
\text { e. Students listen to the lecturer } \\
\text { instructions about the assignments to } \\
\text { be done in the group. } \\
\text { f. Students are assigned to determine } \\
\text { the Nusantara dance and search for } \\
\text { information and videos on the } \\
\text { internet via the media of a laptop or } \\
\text { cellphone. } \\
\text { g. Students observe the agreed } \\
\text { Nusantara video } \\
\text { h. Students identify the elements of the } \\
\text { Nusantara dance that have been } \\
\text { agreed upon including themes, } \\
\text { movement characteristics, music, } \\
\text { costumes, floor patterns, and } \\
\text { properties used. } \\
\text { i. Students discuss the elements of } \\
\text { Nusantara dance in their respective } \\
\text { groups. } \\
\text { Students practice Nusantara dance in } \\
\text { groups guided by lecturers. } \\
\text { k. Students continue the discussion and } \\
\text { practice of Nusantara dance at home. }\end{array}$ \\
\hline 3. & $\begin{array}{l}\text { End } \\
\text { Activity }\end{array}$ & $\begin{array}{l}\text { a. Students and lecturers conclude the } \\
\text { lecture material. } \\
\text { b. Lecturers provide moral messages to } \\
\text { students. } \\
\text { c. The lecturer invites students to pray } \\
\text { at the end of the lecture. }\end{array}$ \\
\hline
\end{tabular}


Table 6. Learning steps The Basic Concepts of Dance Using The Internet In Cycle 2 - Meeting 2

\begin{tabular}{|c|c|c|}
\hline 1. & $\begin{array}{l}\text { First } \\
\text { Activity }\end{array}$ & $\begin{array}{l}\text { a. The lecturer asked all students to } \\
\text { pray apperception and } \\
\text { b. Doing ativating students. } \\
\text { motives and } \\
\text { c. Delivering the objectives activities to be } \\
\text { steps for the actied out. }\end{array}$ \\
\hline 2. & $\begin{array}{l}\text { Core } \\
\text { Activity }\end{array}$ & $\begin{array}{l}\text { a. Students listen to lecturers' } \\
\text { directions regarding the } \\
\text { activities to be carried out } \\
\text { b. Students continue to practice } \\
\text { Nusantara dance. } \\
\text { c. Lecturers provide guidance and } \\
\text { monitor Nusantara dance } \\
\text { exercises. } \\
\text { d. Students present the results of } \\
\text { their discussions and exercises } \\
\text { in front of the class. } \\
\text { e. Lecturers provide opportunities } \\
\text { for other students to respond to } \\
\text { the results of the presentation of } \\
\text { the speaker group. } \\
\text { f. The lecturer provides input to } \\
\text { each group that is presenting } \\
\text { g. Students reflect on learning } \\
\text { outcomes. }\end{array}$ \\
\hline 3. & $\begin{array}{l}\text { End } \\
\text { Activity }\end{array}$ & $\begin{array}{l}\text { a. Students and lecturers conclude } \\
\text { the lecture material. } \\
\text { b. Lecturers provide moral } \\
\text { messages to students. } \\
\text { c. The lecturer invites students to } \\
\text { pray at the end of the lecture. }\end{array}$ \\
\hline
\end{tabular}

The results of observations of student activities in learning the Basic Concepts of Dance with the use of the internet can be seen in table 2 .

Table 7. Data on the observation of student activities in cycle 2

\begin{tabular}{l|c|c}
\hline \multicolumn{1}{c|}{ Criteria } & Total Score & Percentage (\%) \\
\hline Less & - & - \\
\hline Enough & - & - \\
\hline Good & 6 & 42.86 \\
\hline Very Good & 8 & 57.14 \\
\hline
\end{tabular}

\subsection{Discussion}

Learning activities use the internet to get information about Nusantara dance, namely dance themes, forms of motion, accompanying music and properties used to make students more active in learning. Students do not need to secretly access the internet using either a cell phone or laptop. Thus students can freely discuss the dance they are looking for with the lecturer, where the internet provides all information, can replace the manual library position and help complete lecture assignments [5] In addition, integrating the internet in learning can also increase student activity and creativity [6]
Based on the data that has been obtained, it shows that student learning activities increase in cycle 2 . This is indicated by an increase in the number of percentages that increase from cycle 1 to cycle 2 . Student activities increase from cycle 1 to cycle 2 . In cycle 1 , student activities are in the fair category $35.71 \%$, and $64.29 \%$ are in the good category. In cycle 1 there are still aspects that are in the sufficient category, but in cycle 2 these aspects are no longer there. This can be seen from the data, namely $42.86 \%$ are in the good category and 57.14 are in the very good category.

The legality of the internet in learning can provide benefits for students. This can be seen in the student activities in cycles 1 and 2 in the following table 8 and figure 1.

Table 8. The difference in student activity in cycle 1 and cycle 2

\begin{tabular}{l|l|l}
\hline Criteria & $\begin{array}{c}\text { Cycle 1 } \\
(\boldsymbol{\%})\end{array}$ & $\begin{array}{c}\text { Cycle 2 } \\
(\boldsymbol{\%})\end{array}$ \\
\hline Less & - & - \\
\hline Enough & 35.71 & - \\
\hline Good & 64.29 & 42.86 \\
\hline Very Good & - & 57.14 \\
\hline
\end{tabular}

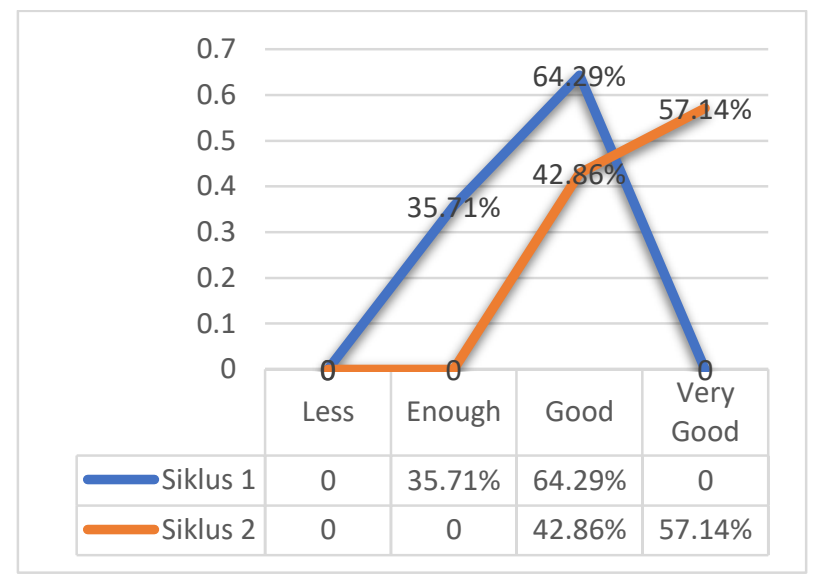

Figure 1 . The difference in student activity in cycle 1 and cycle 2

As has been said before, the internet provides a variety of information about everything. Previous studies have used the internet as a library [1], integrated active learning and internet-based learning [2] and made LED light control devices [3]. In this research, the internet, more specifically Google and Youtube, is utilized for learning Nusantara dance, in which the existence of Nusantara dance throughout Indonesia cannot be reached by students both in terms of time and money. However, students must learn the dance, because this is one of the competencies that must be mastered by students of the PGSD Study Program, Bengkulu University. This is a provision for students to be able to teach dance in accordance with the field in which they teach later. Because in fact, learning dance based on local wisdom can build national character and give birth to a dignified cultural heir who has a national 
identity [15]. Learning traditional dance can be easily understood by elementary school students because at this age they can quickly memorize movements [16]. However, teachers must use the right model so that learning becomes active, innovative and creative [17].

Learning dance is something that is not necessarily mastered by students. Although the internet provides all the information about Nusantara dance, students understand that this information requires another source to confirm its correctness. Students understand that the internet is a source of knowledge [18]. Lecturers are the main learning resource for students. For this reason, lecturers must understand the characteristics of their students in determining the right choice of strategies in online learning so that learning objectives can be achieved [19].

\section{CONCLUSION}

Learning the basic concepts of dance by using Google and YouTube can increase student learning activities. The legality of using cellphones and laptops to access Google and Youtube is a supporting factor for this. Students can freely search for various information about the required archipelago dance material and get guidance from the lecturers who teach these courses.

Based on this, it can be seen that Google and Youtube can make it easier for students to complete their assignments, and the legality of loading students is motivated to complete assignments well.

\section{ACKNOWLEDGMENT}

This research is supported by the University of Bengkulu through the Teacher Training and Education Faculty, PGSD Study Program, Lecturers who teach the Basic Concepts of Dance and PGSD students in semester VB.

\section{REFERENCES}

[1] P. I. Kaliky, "Pemanfaatan Internet dalam Pembelajaran Mahasiswa di Universitas Pattimura, Ambon," Jurnal Komunikasi KAREBA., vol. 2, no. 1, pp. 110-120, 2013.

[2] M. Effendi, "Integrasi Pembelajaran Active Learning dan Internet-Based Learning dalam Meningkatkan Keaktifan dan Kreativitas Belajar," Nadwa, vol. 7, no. 2, pp. 283-309, 2016.

[3] D. Prihatmoko, "PENERAPAN INTERNET OF THINGS (IoT) DALAM PEMBELAJARAN DI UNISNU JEPARA," Simetris: Jurnal Teknik Mesin, Elektro dan
Ilmu Komputer, vol. 7, no. 2, pp. 367-574, 2016.

[4] Muhammad Priyono Tri Sulistyanto, Danang Aditya Nugraha, Nurfatika Sari, Novita Karima ,Wahid Asrori, "Implementasi IoT (Internet of Things) dalam pembelajaran di Universitas Kanjuruhan Malang," SMARTICS Journal, vol. 1, no. 1, pp. 20-23, 2015.

[5] D. Geladze, "Using the Internet and Computer Technologies in Learning/Teaching Process," Journal of Education and Practice, vol. 6, no. 2, pp. 67-69, 2015.

[6] R. Setyorini, "Pemanfaatan Internet Sebagai Implementasi ICT dan Sarana Memotivasi Belajar Sastra di Sekolah," in Prosiding Seminar Nasional Teknologi Pendidikan , Indonesia, 2015.

[7] R. Setiyani, "Pemanfaatan Internet Sebagai Sumber Belajar," Jurnal Pendidikan Ekonomi Dinamika Pendidikan, vol. 6, no. 2, pp. 117133,2010

[8] N. M, "Implementasi STudent Center Leaning Berbasis Internet dalam Pembelajaran Geografi Program Pendidikan Non Formal Kejar Paket C," Diklus, vol. 9, no. XI, pp. 107128, 2007.

[9] Y. Yuliati, "Literasi Sains dalam Pembelajaran IPA," Jurnal Cakrawala, vol. 3, no. 2, 2017.

[10] A. Sujana, A. Permanasari, W. Sopandi \& A. Mudzakir, "Literasi kimia mahasiswa PGSD dan guru IPA Sekolah Dasar," Jurnal Pendidikan IPA Indonesia, vol. 3, no. 1, pp. 511, 2014

[11] Z. B. Kassim \& A. R. B. Ahmad, "EPembelajaran: Evolusi Internet dalam Pembelajaran Sepanjang Hayat.," in Proceedings of Regional Coference on Knowledge Integration in ICT Malaysia., Malaysia, 2010.

[12] E. Mulyatiningsih, Metode Penelitian Terapan Bidang Pendidikan, Yogyakarta: Alfabeta., 2011. 
[13] Trianto, Panduan Lengkap Penelitian Tindakan Kelas, Jakarta: Prestasi Pustakaraya, 2011.

[14] S. Arikunto, Prosedur Penelitian Suatu Pendekatan Praktik, Jakarta: Rineka Cipta, 2010.

[15] D. Rosala, "Pembelajaran Seni Budaya Berbasis Kearifan Lokal Dalam Upaya Membangun Pendidikan Karakter Siswa Di Sekolah Dasar," Ritme: Jurnal Seni dan Desain Serta Pembelajarannya, vol. 2, no. 1, pp. 17-26, 2016.

[16] N. V. Sandi, "Pembelajaran Seni Tari Tradisional Di Sekolah Dasar," Jurnal Dialektika Jurusan PGSD, vol. 8, no. 2, pp. 147-161, 2018.

[17] G. Nurseto, W. Lestari, \& Hartono, "Pembelajaran Seni Tari: Aktif, Inovatif dan Kreatif," Catharsis: Journal of Arts Education, vol. 4, no. 2, pp. 115-122, 2015.

[18] H. I. Strømsø \& I. Bråten, "The role of personal epistemology in the self-regulation of internet-based learning," Metacognition Learning, vol. 5, no. 1, pp. 91-111, 2010.

[19] C. S. Chang, E. Z. F. Liu, H. Y. Sung, C. H. Lin, N. S. Chen \& S. S. Cheng, "Effects of online college student's Internet self-efficacy on learning motivation and performance," Innovations in Education and Teaching International, vol. 51, no. 4, p. 12, 2014. 